\title{
人工衛星構体の搭載機器パネルの音響振動解析*
}

\author{
安 藤 成 将*1, 施 勤 忠*2
}

\section{Vibroacoustic Analysis of Satellite Equipment Panel}

\author{
Shigemasa $\mathrm{ANDO}^{* 3}$ and Qinzhong SHI \\ ${ }^{* 3}$ Japan Aerospace Exploration Agency, \\ 2-1-1 Sengen, Tsukuba-shi, Ibaraki, 305-8505 Japan
}

\begin{abstract}
This paper is concerned with the vibroacoustic response of satellite equipment panel subjected to high frequency diffused acoustic field excitation. Various prediction methods for the response have been developed, namely: ( i ) mass ratio method, (ii) NASA Lewis method, and (iii) impedance method. The prediction accuracy of those methods, however, is poor for the case where the structure of the equipment is distributed in small area of the panel and can be regarded as a plate. In this paper, the new method dealing with that case in particular is developed considering area impedance coupling between equipment and satellite panel. The acoustic excitation experiments for nine cases of equipment mount are conducted to compare the exiting methods with the new method developed in this paiper. The result from the comparison shows that the new method provides a wide flexibility not only for the case of main concern but also for the case of large area equipment where Lewis method may be the best approach for the prediction.
\end{abstract}

Key Words : Acoustic, Forced Vibration, Space Engineering, Statistical Energy Analysis, Satellite Panel, Equipment, Mount

\section{1. 粕}

宇宙機の各搭載機器は, ロケット打上時の 130 デシベル以上の音響加振により，過酷な高周波ラン ダム振動環境に晒される.このため各搭載機器のラ ンダム振動レベルをフライト環境条件として, 搭載 機器の設計を行う必要がある. これらのランダム振 動条件は，10kHz に及ぶ高周波応答であるため， 通常は統計的エネルギ一解析 ${ }^{(1)}$ (Statistical Energy Analysis, SEA）により予測が行われる.

大型衛星は複数のハニカムサンドイッチ平板や 円筒を結合した複雑な構造であるが, 著者らの論文 では, 最も厳しい音響負荷に曝されている外面パネ ル上の搭載機器等のコンポーネントの音響振動解析 は，平板 1 枚と音場のみとした SEA モデルの簡易 化が有効であることを示した(2). SEA の予測結果と して得られるのは, 衛星構体の搭載機器パネルの空 間平均エネルギー（空間二乗平均加速度）である.

\footnotetext{
* 原稿受付 2005 年 9 月 12 日.

*1 正員, 宇宙航空研究開発機構 (305-8505つくば市千現 2 1-1) [現：米国カリフォルニア工科大学ジェット推進研究所 客員研究員].

*2 正員, 宇宙航空研究開発機構.

E-mail : ando.shigemasa@jaxa.jp
}

しかし，現実では，図1のように衛星構体パネルに 多くのボックス状の機器が搭載されている. 搭載機 器とパネル結合部のランダム振動加速度は搭載機器 の設計基準となり，搭載機器の影響を考慮した SEA 予測手法が必要となる. 従来は, 搭載機器の 有無により平板のエネルギ一は不変と仮定した手法 (3)，搭載機器の質量は平板全体に一様に分布してい ると仮定した手法 ${ }^{(4)}$, 搭載機器は質点として衛星構 体パネルに作用すると仮定したインピーダンス手法 (5)等により搭載機器のある衛星構体パネルの予測が 行なわれてきた. しかし, 搭載機器の総面積が狭く 平板形態である場合では，従来の手法 ${ }^{(3-5)}$ は予測が 困難であった，そこで，本稿では，搭載機器と衛星 構体パネルが面で結合する新たなインピーダンスモ デルを提案し，音響加振実験によりこのモデルの妥 当性を検証し, 従来の手法 ${ }^{(3-9)}$ との比較考察を行う. また, 本稿で提案する手法は, 搭載機器の損失係数 の影響を考慮することが出来るため, 損失係数の值 に基づいた安全側の予測法についても議論する. 


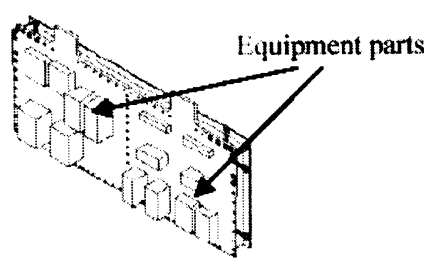

Fig. 1 Example of satellite equipment panel

\section{SEAによる平板の音需振㲜解析}

拡散音場により両面加振される機器を搭載しない平 板の応答は, 拡散音場と平板構造の 2 要素 SEA モデ ルにより，片側の音響放射効率を 2 倍にして次式で予 測することが出来る゙。.

$$
\begin{aligned}
&\left\langle a^{2}\right\rangle=\frac{2 \pi^{2} c_{0} n_{2}\left\langle p^{2}\right\rangle}{\rho_{0} M} \times \frac{1}{1+\eta_{2} M \omega / 2 \rho_{0} c_{0} S \sigma_{r a d}}(1) \\
& こ こ に, \text { 平板の二乗加速度の時間・空間二乗平均 } \\
&\left\langle a^{2}\right\rangle: \text { 二乘拡散音圧の時間・空間二乗平均 } \\
&\left\langle p^{2}\right\rangle: \text { 空気密度 } \\
& \rho_{0}: \text { 空気音速 } \\
& c_{0}: \text { 平板の面密度 } \\
& \rho h: \text { 平板の面積 } \\
& n_{2}: \text { 平板のモ一ト密度 } \\
& \eta_{2}: \text { 平板の損失釈数 } \\
& \sigma_{r a d}: \text { 平板の放射効率 } \\
& M: \text { 平板の質量 } \\
& \omega: \text { 角周波数 } \\
& \text { である. } \text { ここで, } n_{2} \text { は単位角周波数あたりのモード } \\
& \text { 数である. }
\end{aligned}
$$

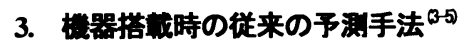

式(1)は，抬散音響負荷時の衛星パネルに搭載機器を 考慮しない均一平板の空間平均加速度と空間平均音圧 の関係を示しており，搭载機器の影響を予測すること が設計上求められる. 以下, 搭載機器の影響を求める 従来の方法を紹介し，適用対象について議論する.

\section{3・1 其此による手法 (Mass Ratio Method)}

質量比による手法では, 搭載機器の有無に関わら ずパネル自身の損失係数・モード密度・クリティカル 周波数は不変であり, 搭載機器は剛体としてエネルギ 一を持ち, 搭載機器による平板への剛性強化の効果は 無いと仮定する. さらに, 搭載機器の有無により平板 のエネルギーが不変と仮定すると, 両面音響負荷にお ける機器搭載時の搭載機器の加速度は,

$$
\begin{aligned}
& \left\langle a^{2}\right\rangle_{L}=\frac{M}{M+M_{c}}\left\langle a^{2}\right\rangle \\
& =\frac{2 \pi^{2} c_{0} n_{2}\left\langle p^{2}\right\rangle}{\rho_{0}\left(M+M_{c}\right)} \times \frac{1}{1+\eta_{2} M \omega / 2 \rho_{0} c_{0} S \sigma_{r a d}}
\end{aligned}
$$

となる. ここに, $M$ は平板質量, $M_{c}$ は搭載機器質 量, $\left\langle a^{2}\right\rangle_{L}$ は機器搭載時の搭載機器の加速度である. モード密度 $n_{2}$ と放射効率 $\sigma_{\text {rad }}$ については機器が無い 場合の面密度加計算する.

\section{3-2 一梾分布貿量とする手法 (Lewis Method)} この手法は, NASA Lewis Research Center（現 Glenn Research Center) で開発された手法であり， 搭載機器の有無に関わらず平板のモード密度とクリテ ィカル周波数が不変であるとし, 機器質量は平板に一 様に塗付けられていると仮定する. その時, 両面音響 負荷における機器搭載時の搭載機器の加速度は,

$$
\left\langle a^{2}\right\rangle_{L}=\frac{2 \pi^{2} c_{0} n_{2}\left\langle p^{2}\right\rangle}{\rho_{0}\left(M+M_{c}\right)} \times \frac{1}{1+\eta_{2}\left(M+M_{c}\right) \omega / 2 \rho_{0} c_{0} S \sigma_{r a d}}
$$

となる. モード密度 $n_{2}$ と放射効率 $\sigma_{r a d}$ については機 器が無い場合の面密度から計算する.

\section{3-3 インピーダンス(Impedance)による手法の}

図 2 に示すように, 外力 $F_{d}$ を受ける構造 $p$ に搭載 機器 $m$ が結合点 $i$ を介して結合されているものとする. $p$ と $m$ が末結合で境界自由支持の境界条件での $i$ に おける駆動点インピーダンスを $Z_{i i}^{p}, Z_{i i}^{m}$ とする. こ のとき, 機器 $m$ が無い場合の構造 $p$ の $i$ における速度 を $X_{i 0}^{p}$ とし, 搭載機器の有無により外力（音響負荷 圧）が不変と仮定すれば, 結合後の機器 $m$ の速度 $X_{i}^{p}$ は次式で書ける日.

$$
X_{i}^{p}=X_{i 0}^{p} \frac{1}{1+Z_{i i}^{m} / Z_{i i}^{p}}
$$

構造 $p$ の結合点 $i$ における駆動点インピーダンスは次 式の無限板のインピーダンスのを使用する.

$$
Z_{i i}^{p}=2 M / \pi n_{2}
$$

また，搭載機器は質点と仮定すると，その駆動点イン ピーダンスは,

$$
Z_{i i}^{m}=j \omega M_{c}
$$

である. 式(1), (4), (5), (6)から両面音響負荷における 機器搭載時の搭載機器の加速度は, 


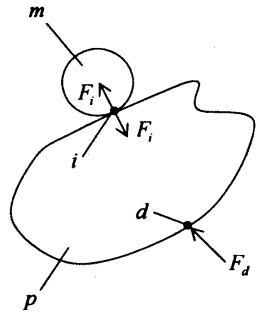

Fig. 2 Equipment mounted structure

$$
\begin{aligned}
& \left\langle a^{2}\right\rangle_{L}=\left|\frac{1}{1+Z_{i i}^{m} / Z_{i i}^{p}}\right|^{2}\left\langle a^{2}\right\rangle=\frac{1}{1+\left(\frac{M_{c}}{M} \frac{\pi \omega n_{2}}{2}\right)^{2}}\left\langle a^{2}\right\rangle \\
& =\frac{2 \pi^{2} c_{0} n_{2}\left\langle p^{2}\right\rangle}{\rho_{0} M} \times \frac{1}{1+\eta_{2} M \omega / 2 \rho_{0} c_{0} S \sigma_{r a d}} \\
& \times \frac{1}{1+\left(\frac{M_{c}}{M} \frac{\pi \omega n_{2}}{2}\right)^{2}}
\end{aligned}
$$

となる. モード密度 $n_{2}$ と放射効率 $\sigma_{r a d}$ については機 器が無い場合の面密度から計算する.

\section{4. 提案する予測手法}

従来のインピーダンス手法では搭載機器を質点と してモデル化するため, 搭載機器が平板の面内方向に 広がった平板形態の構造の場合, 平板の振動応答は実 験結果に対し過少な予測結果となる場合があったの. そこで, 本稿では, インピーダンス手法におけるイン ピーダンス值として一様加振時の力一速度間伝達イン ピーダンスを適用することを考える.

図 3 に示寸ように, 点 $x_{i}$ において角周波数 $\omega$ の面 外集中力 $f_{0}$ を受ける有限平板を考える. このとき, 応答点 $x_{j}$ の速度 $v$ は次式で書ける。

$$
v\left(x_{j}, x_{i}, \omega\right)=\frac{f_{0}}{\hat{m}} \sum_{q} \frac{j \omega \psi_{q}\left(x_{i}\right) \psi_{q}\left(x_{j}\right)}{\omega_{q}^{2}(1+j \eta)-\omega^{2}}
$$

ここに, $q$ はモード次数, $\hat{m}$ は平板の面密度, $\psi$ は 平板のモード形状, $\eta$ は平板の損失俰数， $\omega_{q}$ は固有 振動数である. また, $q, r$ 次のモード直交性を用いて モード形状は式(9)で規格化されている.

$$
\int_{S} \psi_{q} \psi_{r} d x=\delta_{q r}
$$

ここに， $\delta_{q r}$ はクロネッカーデルタである. 式(8)より 集中力 $f_{0}$ と速度 $v$ の伝達モビリティ $Y_{i j}$ は,

$$
Y_{i j}\left(x, x_{s}, \omega\right)=\frac{1}{\hat{m}} \sum_{q} \frac{j \omega \psi_{q}\left(x_{i}\right) \psi_{q}\left(x_{j}\right)}{\omega_{q}^{2}(1+j \eta)-\omega^{2}}
$$

である.

ここで, 図 4 に示すように互いに無相関な加振力 $f_{0}$ が平板全体に一様に作用している一様加振を考え る.このとき，伝達モビリティの空間二乗平均 $\left\langle\left. Y_{i j}(\omega)\right|^{2}\right\rangle$ は, 式(10)に対し, 加振点位置 $x_{i}$ 及び応答 点 $x_{j}$ に関する平板内の空間平均を行なうことにより,

$$
\begin{gathered}
\left\langle\left. Y_{i j}(\omega)\right|^{2}\right\rangle=\frac{\omega^{2}}{\hat{m}^{2} S^{2}} \int_{S}\left\{\int_{S}\left|\sum_{q} \frac{\psi_{q}\left(x_{i}\right) \psi_{q}\left(x_{j}\right)}{\omega_{q}^{2}(1+j \eta)-\omega^{2}}\right|^{2} d x_{i}\right\} d x_{j} \\
=\frac{1}{\hat{m}^{2} S^{2}} \sum_{q} \frac{\omega^{2}}{\left(\omega^{2}-\omega_{q}^{2}\right)^{2}+\eta^{2} \omega_{q}^{4}} \\
\approx \frac{1}{\hat{m}^{2} S^{2}} \sum_{q} \frac{\omega^{2}}{4 \omega^{2}\left(\omega_{q}-\omega\right)^{2}+\eta^{2} \omega^{4}}
\end{gathered}
$$

となる.ここに式(9)の規格化条件を使用し, 軽減衰 $(\eta<1)$ で有効な式(12)の仮定を行った.

$$
\left(\omega^{2}-\omega_{q}^{2}\right)^{2}+\eta^{2} \omega_{q}^{4} \approx 4 \omega^{2}\left(\omega_{q}-\omega\right)^{2}+\eta^{2} \omega^{4}
$$

さらに, 加振力がバント幅 $[\omega, \omega+\Delta \omega]$ を持つバンド ノイズであるとき式(11)のバンド内平均値 $\left\langle\left. Y_{i j}(\omega)\right|^{2}\right\rangle_{\Delta}$ は,

$\left\langle\left. Y_{i j}(\omega)\right|^{2}\right\rangle_{\Delta}=\frac{1}{\hat{m}^{2} S^{2} \Delta \omega} \sum_{q} \int_{\omega}^{\omega+\Delta \omega} \frac{\omega^{2}}{4 \omega^{2}\left(\omega_{q}-\omega\right)^{2}+\eta^{2} \omega^{4}} d \omega$

となる. 軽减衰であれば, 式(13)の被積分項はパルス 状であるため無限大まで積分範囲を拡大することが出 来,

$$
\begin{aligned}
& \int_{\omega}^{\omega+\Delta \omega} \frac{\omega^{2}}{4 \omega^{2}\left(\omega_{q}-\omega\right)^{2}+\eta^{2} \omega^{4}} d \omega \\
& \approx \int_{0}^{\infty} \frac{\omega^{2}}{4 \omega^{2}\left(\omega_{q}-\omega\right)^{2}+\eta^{2} \omega^{4}} d \omega=\frac{\pi}{2 \eta \omega_{q}}
\end{aligned}
$$

となる. 従って, 式(13)は

$$
\left\langle\left. Y_{i j}(\omega)\right|^{2}\right\rangle_{\Delta}=\frac{1}{\hat{m}^{2} S^{2} \Delta \omega} \sum_{q} \frac{\pi}{2 \eta \omega_{q}} \approx \frac{\pi}{2 \hat{m}^{2} S^{2} \eta_{2} \omega} \frac{\Delta N}{\Delta \omega}
$$

となる.

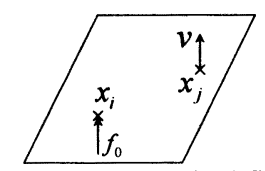

Fig. 3 Point force excited finite plate 


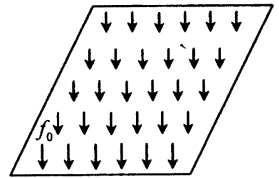

Fig. 4 Uniformly distributed excitation

ここに, $\omega_{q}$ をバンド中心周波数 $\omega$ と置き換え, 各 モ一ドの損失係数は一定 $\eta_{2}$ とし， $\Delta \omega$ 中に含まれる 平板のモードの個数を $\Delta N$ 個とした.

式(15)の $\Delta N / \Delta \omega$ はモード密度であり $n_{2}$ と表記し, $\hat{m} S$ は平板の質量 $M$ であるから式(15)は

$$
\left\langle\left. Y_{i j}(\omega)\right|^{2}\right\rangle_{\Delta}=\frac{\pi n_{2}}{2 M^{2} \omega \eta_{2}}
$$

とも書くことが出来る. 従って, 空間平均, 及びバン ド内平均されたモビリティから求まる二乗平均伝達イ ンピーダンス $\left|Z_{i j}\right|^{2}$ は,

$$
\left|Z_{i j}\right|^{2}=\frac{1}{\left\langle\left|Y_{i j}(\omega)\right|^{2}\right\rangle_{\Delta}}=\frac{2 M^{2} \omega \eta_{2}}{\pi n_{2}}
$$

となる. 次に, 伝達モビリティの実部と虚部である

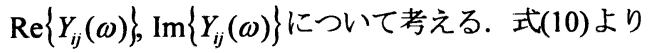
これらは,

$$
\begin{aligned}
& \operatorname{Re}\left\{Y_{i j}(\omega)\right\}=\frac{1}{\hat{m}} \sum_{q} \frac{\eta \omega^{3} \psi_{q}\left(x_{i}\right) \psi_{q}\left(x_{j}\right)}{\left(\omega^{2}-\omega_{q}^{2}\right)^{2}+\eta^{2} \omega_{q}^{4}} \\
& \operatorname{Im}\left\{Y_{i j}(\omega)\right\}=\frac{1}{\hat{m}} \sum_{q} \frac{\omega\left(\omega^{2}-\omega_{q}^{2}\right) \psi_{q}\left(x_{i}\right) \psi_{q}\left(x_{j}\right)}{\left(\omega^{2}-\omega_{q}^{2}\right)^{2}+\eta^{2} \omega_{q}^{4}}
\end{aligned}
$$

である. 式(18), (19)について, 式(11)と同様に, 加 振点位置 $x_{i}$ 及び応答点 $x_{j}$ に関する平板内の空間平均 を行なうと,

$$
\begin{gathered}
\left\langle\operatorname{Re}\left\{Y_{i j}(\omega)\right\}\right\rangle=\frac{1}{\hat{m} S^{2}} \sum_{q} \frac{\eta \omega^{3} \int_{S} \psi_{q}\left(x_{i}\right) d s \int_{S} \psi_{q}\left(x_{j}\right) d s}{\left(\omega^{2}-\omega_{q}^{2}\right)^{2}+\eta^{2} \omega_{q}^{4}} \\
=\frac{1 /}{\hat{m} S^{2}} \sum_{q} \frac{\eta \omega^{3} y_{q}}{\left(\omega^{2}-\omega_{q}^{2}\right)^{2}+\eta^{2} \omega_{q}^{4}}
\end{gathered}
$$$$
\left\langle\operatorname{Im}\left\{Y_{i j}(\omega)\right\}\right\rangle=\frac{1}{\hat{m} S^{2}} \sum_{q} \frac{\omega\left(\omega^{2}-\omega_{q}^{2}\right) y_{q}}{\left(\omega^{2}-\omega_{q}^{2}\right)^{2}+\eta^{2} \omega_{q}^{4}}
$$

$y_{q}=\left\{\int_{S} \psi_{q}(x) d x\right\}^{2}$

となる.ここに， $y_{q}$ は $q$ 次モードのモード形状の面 積分の二乗である. さらに，式(13)と同様に，式(12) の仮定を適用すれば，式(20)，(21)のバンド内平均值 $\left\langle\operatorname{Re}\left\{Y_{i j}(\omega)\right\}\right\rangle_{\Delta},\left\langle\operatorname{Im}\left\{Y_{i j}(\omega)\right\}\right\rangle_{\Delta}$ は, 式(23), (24)の積分 結果より，式(25), (26)となる.

$$
\begin{gathered}
\int_{\omega}^{\omega+\Delta \omega} \frac{\omega\left(\omega^{2}-\omega_{q}^{2}\right)}{4 \omega^{2}\left(\omega_{q}-\omega\right)^{2}+\eta^{2} \omega^{4}} d \omega \\
\approx \int_{0}^{\infty} \frac{\omega\left(\omega^{2}-\omega_{q}^{2}\right)}{4 \omega^{2}\left(\omega_{q}-\omega\right)^{2}+\eta^{2} \omega^{4}} d \omega=0 \\
\int_{\omega}^{\omega+\Delta \omega} \frac{\eta \omega^{3}}{4 \omega^{2}\left(\omega_{q}-\omega\right)^{2}+\eta^{2} \omega^{4}} d \omega \\
\approx \int_{0}^{\infty} \frac{\eta \omega^{3}}{4 \omega^{2}\left(\omega_{q}-\omega\right)^{2}+\eta^{2} \omega^{4}} d \omega=\frac{\pi}{2} \\
\left\langle\operatorname{Re}\left\{Y_{i j}(\omega)\right\}\right\rangle_{\Delta}=\frac{1}{\hat{m} S^{2} \Delta \omega} \sum_{q}\left[y_{q} \times\right. \\
\left.\int_{\omega}^{\omega+\Delta \omega} \frac{\eta \omega^{3}}{4 \omega^{2}\left(\omega_{q}-\omega\right)^{2}+\eta^{2} \omega^{4}} d \omega\right] \\
=\frac{1}{\hat{m} S^{2} \Delta \omega}\left\{\frac{\pi y_{q}}{2}\right. \\
=0 \\
\left.\int_{\omega}^{\omega+\Delta \omega} \frac{\omega\left(\omega^{2}-\omega_{q}^{2}\right)}{4 \omega^{2}\left(\omega_{q}-\omega\right)^{2}+\eta^{2} \omega^{4}} d \omega\right]
\end{gathered}
$$

即ち, 空間平均, 及びバンド内平均された平均伝達モ ビリティの虚部はゼロである. 一方, 平均伝達モビリ ティの実部は， $y_{q}$ が殆どのモードでゼロとなるのこと から $\left\langle\operatorname{Re}\left\{Y_{i j}(\omega)\right\}\right\rangle_{\Delta}=0$ であり，一様加振下で物理的 に意味のある伝達モビリティは式(16)の二乗平均伝達 モビリティであることが分かる.

ここで, 式(16), (17), (25), (26)のモビリティとイン ピーダンスを搭載機器び平板に適用することを考える. 搭載機器の二乗平均伝達モビリティと平均伝達モビリ ティをそれぞれ $\left|Y_{i j}^{m}\right|^{2}, Y_{i j}^{m}$ ，平板のそれらを $\left|Y_{i j}^{p}\right|^{2}, Y_{i j}^{p}$ とすれば,

$$
\begin{aligned}
& \left|\frac{1}{1+Z_{i j}^{m} / Z_{i j}^{p}}\right|^{2}=\frac{\left|Y_{i j}^{m}\right|^{2}}{\left|Y_{i j}^{m}\right|^{2}+\left|Y_{i j}^{p}\right|^{2}+Y_{i j}^{p} \bar{Y}_{i j}^{m}+\bar{Y}_{i j}^{p} Y_{i j}^{m}} \\
& =\frac{\left|Y_{i j}^{m}\right|^{2}}{\left|Y_{i j}^{m}\right|^{2}+\left|Y_{i j}^{p}\right|^{2}}=\frac{\left|Z_{i j}^{p}\right|^{2}}{\left|Z_{i j}^{p}\right|^{2}+\left|Z_{i j}^{m}\right|^{2}}
\end{aligned}
$$

となる.ここに, $\left|Z_{i j}^{m}\right|^{2},\left|Z_{i j}^{p}\right|^{2}$ は搭載機器及び平板の 二乗平均伝達インピーダンスであり, $\bar{Y}_{i j}^{m}$ は $Y_{i j}^{m}$ の共 役複素数である. また，平均伝達モビリティの実部， 虚部共に 0 である性質を使用した.ここで, 式(4)中 で, 駆動点インピーダンス $Z_{i i}^{m}, Z_{i i}^{p}$ の代わりに, 伝達 インピーダンス $Z_{i j}^{m}, Z_{i j}^{p}$ を代入し, 面で結合すること を考える. この時, 式(27)の関係式から，両面音響負 荷における機器搭載時の搭載機器の加速度は, 
Table 1 Equipment properties of various patterns

\begin{tabular}{c|c|c|c|c|c}
\hline No & Length $\times$ Width $\times$ Height(mm) & Mass(kg) & Area mass $\left(\mathrm{kg} / \mathrm{m}^{2}\right)$ & Number of Mass & $\begin{array}{c}\text { Estimated first } \\
\text { natural frequency(Hz) }\end{array}$ \\
\hline Pattern1 & $180 \times 300 \times 12$ & 5 & 92.6 & 3 & 663 \\
Pattern2 & $180 \times 300 \times 12$ & 5 & 92.6 & 6 & 663 \\
Pattern3 & $180 \times 300 \times 12$ & 5 & 92.6 & 9 & 663 \\
Pattern4 & $180 \times 300 \times 12$ & 5 & 92.6 & 1 & 663 \\
Pattern5 & $180 \times 300 \times 24$ & 20 & 185 & 1 & 1327 \\
Pattern6 & $180 \times 300 \times 48$ & 20 & 370 & 1 & 2653 \\
Pattern7 & $180 \times 300 \times 48$ & 20 & 91.6 & 1 & 2653 \\
Pattern8 & $590 \times 370 \times 12$ & 35 & 94.3 & 1 & 165 \\
Pattern9 & $765 \times 485 \times 12$ & & 1 & 96 \\
\hline
\end{tabular}

$$
\begin{gathered}
\left\langle a^{2}\right\rangle_{L}=\left|\frac{1}{1+Z_{i j}^{m} / Z_{i j}^{p}}\right|^{2}\left\langle a^{2}\right\rangle=\frac{1}{1+\left|Z_{i j}^{m}\right|^{2} /\left|Z_{i j}^{p}\right|^{2}}\left\langle a^{2}\right\rangle \\
=\left\langle p^{2}\right\rangle \times \frac{2 \pi^{2} c_{0} n_{2}}{\rho_{0} M} \times \frac{1}{1+\eta_{2} M \omega / 2 \rho_{0} c_{0} S \sigma_{r a d}} \\
\times \frac{1}{1+\left(\frac{M_{c}}{M}\right)^{2} \frac{n_{2}}{n_{c}} \frac{\eta_{c}}{\eta_{2}}}
\end{gathered}
$$

で得られる.ここに, $n_{c}, \eta_{c}$ はそれぞれ搭載機器のモ 一ド密度と損失俰数である. また, モード密度 $n_{2}$ と 放射効率 $\sigma_{r a d}$ については機器が無い場合の面密度か ら計算する.

\section{5. 音霸加振実鍂による検証}

\section{$5 \cdot 1$ 供試体}

機器を搭載する衛星構体パネルとして, 維横長さ が $1.82 \mathrm{~m} \times 0.91 \mathrm{~m}$ で, アルミニウムスキンの厚さは $0.3 \mathrm{~mm}$, アルミニウムハニカムコアの厚さは $25 \mathrm{~mm}$ であり, 機器搭載のためのインサート等を含めた総質 量は $7.6 \mathrm{~kg}$ とする. 衛星構体パネルのクリティカル周 波数は $487 \mathrm{~Hz}$ で一次固有振動数は $110 \mathrm{~Hz}$ である. また，各1/3 オクターブバンド当たりのモード数は, $200 \mathrm{~Hz}$ バンド以上の周波数バンドで 2 個以上となる.

搭載機器の材料を SS400 として, 図 5 に示す 9 種 類の搭載パターンで実験を行なった. また, 搭載機器 の詳細を表 1 に示す。
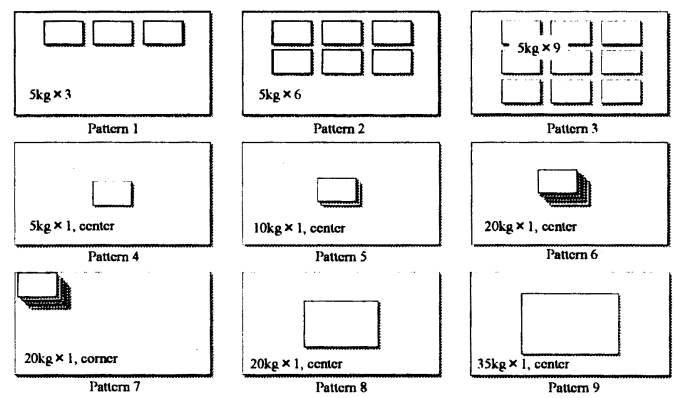

Fig. 5 Mount patterns of equipments

\section{5 - 2 音霸加振実検}

9 種類の搭載パターンについて音響加振実験を行 った. 音響加振実験は, 宇宙航空研究開発機構筑波宇 宙センター総合環境試験棟 $1600 \mathrm{~m}^{3}$ 音響圾験設備で行 った. 拡散音場となる直方体形状の反響室の容積は $1607 \mathrm{~m}^{3}(17.1 \mathrm{~m} \times 10.5 \mathrm{~m} \times 9.0 \mathrm{~m})$ であり, 供試体の 無い空音場時の最大音圧レベルは $151 \mathrm{~dB}$ である. 音 響加振実験の加音レベルは, オーバーオールで $141.5 \mathrm{~dB}$ であり, バンドノイズ加振である. 搭載機器 上で 4〜8 点, 機器を搭載していない平板上で 4〜8 点の面外方向加速度の計測を行った. 衛星構体パネル は, 衛星構体搭載時之同様な境界条件を模擬する治具 と一定間隔のインサートボルトにより四辺を支持され ている.

\section{3 結果の比较及び考察}

第 3 章で示した従来の予測手法と本稿で提案す る予測手法により，9 種類の搭載パターンについて解 析を行った. 解析で必要となる衛星構体パネルの放射 効率は参考文献のモデルを用いた。 モード密度 $n_{c}, n_{2}$ は $n=(S / 4 \pi)(\rho h / D)^{1 / 2}$ により計算した ${ }^{00}$.こ こに $S$ は平板の面積, $D$ は平板の曲け用性である. SS400 の平板である搭載機器は損失係数 $\eta_{2}$ への影響 は小さいと考え, $\eta_{2}$ は搭載前後で一定と仮定し, 搭 載機器の無い平板の損失係数実験データを検討し次式 で与えた.

$$
\eta_{2}= \begin{cases}0.1 & (f \leq 125 \mathrm{~Hz}) \\ 12.5 / f & (f>125 \mathrm{~Hz})\end{cases}
$$

また，本稿で提案する手法式(28)において，搭載機 器と平板の損失係数は等しい $\eta_{c}=\eta_{2}$ と仮定した. 搭 載機器の損失係数 $\eta_{c}$ の解析結果への影響については 後述する. また, 表 1 中の搭載機器の一次固有振動 数 $\omega_{0}$ は, 文献(11)の簡易式 $\omega_{0}=1 / n$ により計算した.

図 6〜図 14 に解析結果と実験結果の比較を示寸. 図中において”Experiment-Plate”とは機器を搭載し ていない平板領域の空間二乗平均加速度（実験結果） であり, 'Experiment-Mass"とは搭載機器上の空間 
二乗平均加速度 (実験結果) である. 各手法の予測結 果は, "Experiment-Mass"と比較評価を行う. Pattern によって, Experiment-Plate が異なるのは, 搭載機器 の質量により, 機器を搭載していない領域の応答も影 響を受けるためである.

搭載機器の総面積が広い Pattern 2, 3, 8, 9 について は, Lewis Method が実験結果と最も良く一致してい る.これは, Lewis Method は搭載機器を平板上の一 様分布質量として予測する手法であるからと考えられ る. 一方, 質量比による手法は, Lewis Method に比 較して, 3-10dB 大きな結果であり全ての搭載パター ンにおいて質量上の実験結果に比べ，最大で $20 \mathrm{~dB}$ 以 上の過大な結果となった.

搭載機器を 1 点に集中した質点として扱う従来のイ ンピーダンス手法の結果は, 全ての搭載パターンにお いて $20 \mathrm{~dB}$ 以上の過少な予測結果となっているが, 最 も集中質量（質点）に近い Pattern 6 において, $200 \mathrm{~Hz}$ 以上で実験結果と傾向は良く一致している. この手法は機器搭載時の応答の下限值を与えると考え られるが, 質点に近い搭載パターン以外では過少な予 測結果となる.

次に, 本稿で提案する手法式(28)は, 搭載機器を平 板と仮定しているため, Pattern 4, 5, 6, 8, 9 のような 搭載機器が平板様である搭載パターンにおいて $250 \mathrm{~Hz} \sim 2000 \mathrm{~Hz}$ で実験結果と $10 \mathrm{~dB}$ 以内で一致して いる. また, 機器総面積の広い Pattern 1, 2, 8, 9 にお いて本稿の手法は, Lewis Method と 10dB 以内で一 致している，注目すべきことは，従来の Lewis Method や Impedance Method で予測精度が悪い Pattern 4, 5, 6 において, 本稿の手法のみが実験結果 と $300 \mathrm{~Hz}$ 以上において $10 \mathrm{~dB}$ 以内で良く一致してい ることである. 本稿で提案する手法は, 搭載機器のモ 一ド密度を用いているため, 表 1 に示す搭載機器の一 次固有振動数以上で有効と考えられるが, 従来の Impedance Method で過小となり, Lewis Method で 過大となる予測結果の傾向を緩和することが出来たと 言える.このことは，あるシフト周波数以上において， 搭載機器は一様分布質量や質点ではなく弾性を持った 構造体としてモデル化する必要があることを示してい る. 例えば, 図 10 に示すように, Pattern 5 では, $300 \mathrm{~Hz}$ を境界として, 実験結果と一致する手法が Lewis Method から本稿で提案する手法式(28)にシフ トしている.このシフト周波数の予測が高精度化には 不可欠であるが, 今後の課題である.

Pattern 6 の搭載機器位置を隅点にした Pattern 7 は $300 \mathrm{~Hz}$ 以上において全ての手法で予測が困難であっ
た.これは，曲げ波に対する境界の影響のため SEA の仮定が成立しないためと考えられる.

次に, Pattern 4, 5, 9 について, 搭載機器と平板の 損失係数比 $\alpha=\eta_{c} / \eta_{2}$ を 0.1 から 10 まで変化させた 場合の式(28)による予測結果と実験の比較を図 15〜 図 17 に示す. 搭載機器の損失係数が大きい程, 応答 は小さくなる傾向があり, 実験結果に近い $\alpha$ は Pattern 4 では 2.0, Pattern 5, 9 では 1.0 であった. また, $\alpha$ を 0.5 とした解析結果は, $400 \mathrm{~Hz}$ 以上の周 波数で Pattern 4,5,9 の実験結果を良好に包絡している. 実際の搭載機器は，配線や接合部等により本稿の搭載 質量よりも損失係数が大きい $(\alpha$ が大)ので, 現実の衛 星設計において $\alpha$ を 0.5 とした式(28)の解析結果は安 全側の予測結果を与えると考えられる.

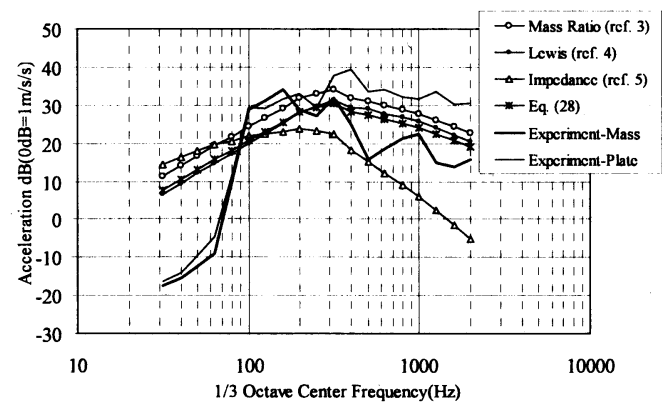

Fig. 6 Analysis result for pattern 1

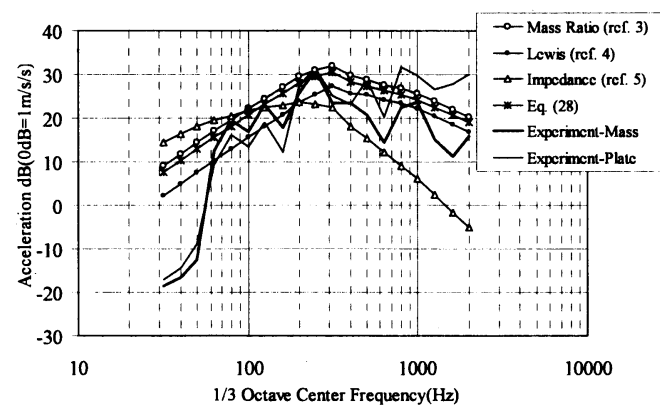

Fig. 7 Analysis result for pattern 2

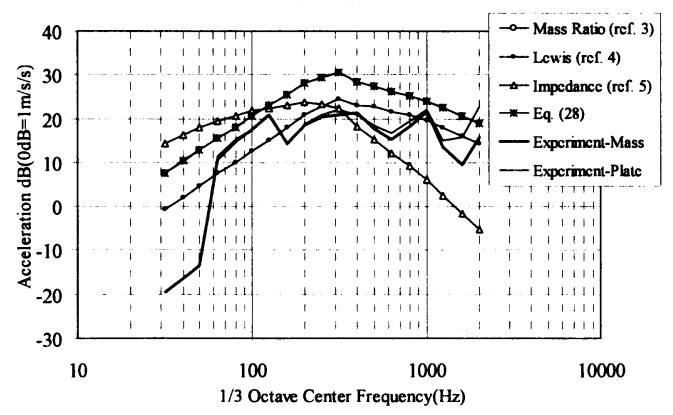

Fig. 8 Analysis result for pattern 3 


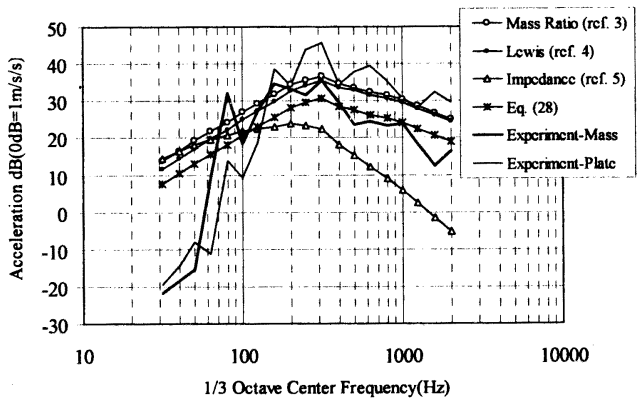

Fig. 9 Analysis result for pattern 4

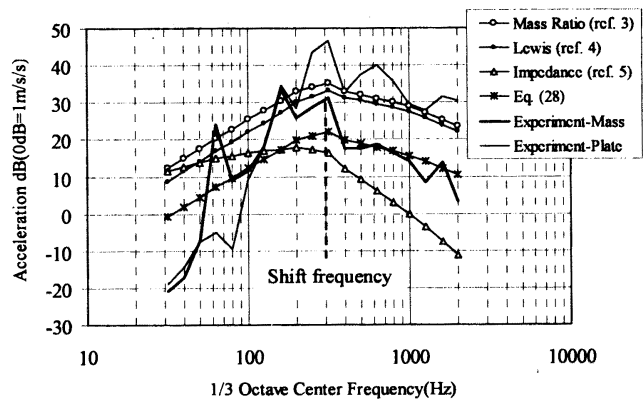

Fig. 10 Analysis result for pattern 5

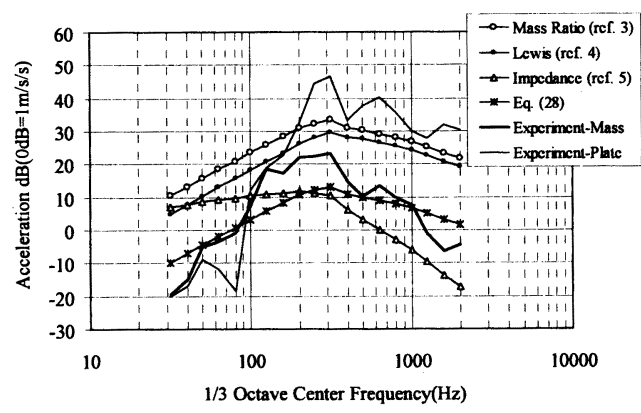

Fig. 11 Analysis result for pattern 6

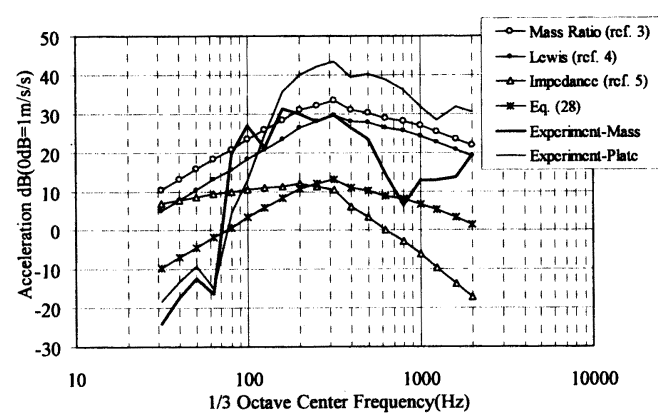

Fig. 12 Analysis result for pattern 7

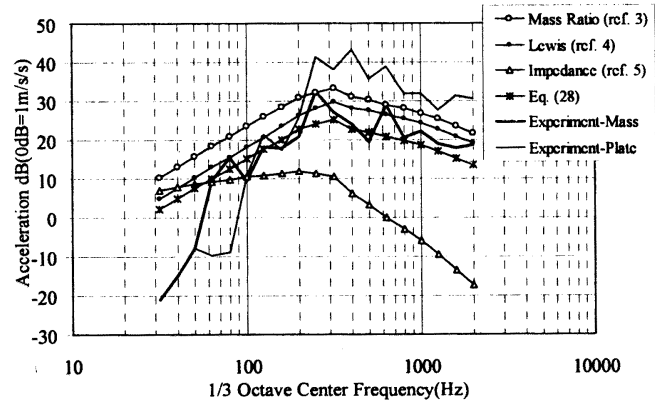

Fig. 13 Analysis result for pattern 8

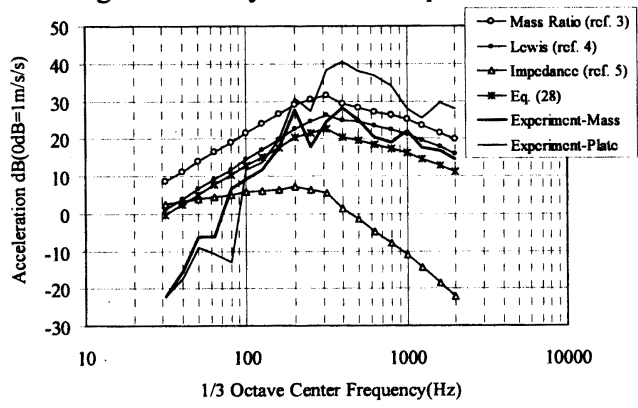

Fig. 14 Analysis result for pattern 9

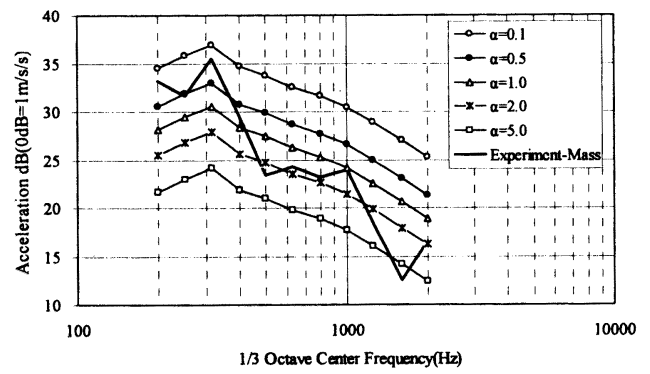

Fig. 15 Analysis result of various damping loss factor ratios for pattern 4

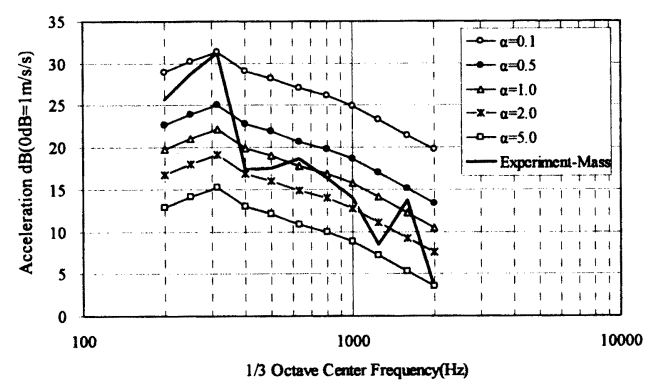

Fig. 16 Analysis result of various damping loss factor ratios for pattern 5 


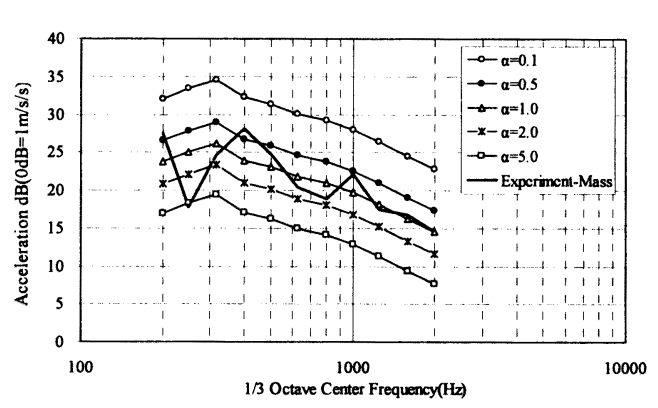

Fig. 17 Analysis result of various damping loss factor ratios for pattern 9

\section{6. 結詥及び今後の課題}

本稿は, 拡散音場加振を受ける機器を搭載した衛星 用平板について, 統計的エネルギ一解析を用いた応答 加速度予測法の研究を行った. 従来, 予測が困難であ った搭載機器の総面積が小さい搭載形態の場合につい て，新たな手法を提案した. 9 種類の搭載パターンに 対し音響加振実験を行い，本稿で提案した手法と従来 の手法の比較を行なった. 本研究の成果として結論を 以下の通りまとめる.

(1) 機器が衛星構体パネルの面内方向に広がった搭 載形態の構造の場合について, 面インピーダン スに基づいた新たな予測手法を提案した.

（2）新たな予測手法と従来の予測手法について，音 響加振実験により検証を行い, 搭載機器の総面 積が広い搭載形態では, Lewis Method が最も精 度が良いが，本稿の手法も実験結果と $10 \mathrm{~dB}$ 以内 で良く一致することを示した。

(3) 従来の Lewis Method や Impedance Method で 予測が困難な総面積の少ない搭載形態について は, 本稿で提案する手法のみが精度良く予測可 能であることを示した.

（4）本稿で提案する手法は，搭載機器の損失俰数の 影響を考慮する事が出来, 平板との損失係数比 を 0.5 と与えれば安全側の設計条件となることを 示した.

機器搭載時の音響振重動答予測のさらなる高精度化 には, 搭載機器が一様分布質量や質点ではなく弾性を 持った構造体として挙動するシフト周波数の予測, 及 び各予測手法の適用範用・適用周波数範用の検討が不 可欠であるが, これは今後の課題である.

\section{謝辞}

本研究では, 宇宙航空研究開発機構 試験センター と三菱電機(株との委託契約において取得した試験デー タを使用させて頂いた，関係各位に感謝する．また， 本研究の実施に当たり, 著者の所属するカリフォルニ ア工科大学ジェット推進研究所の Dennis Kern 氏, 及び Juan Fernandez 氏より貴重な助言を頂いたこと に感謝する.

\section{参考文献}

(1) Lyon, R.H. and De Jong, R.G., Theory and Application of Statistical Energy Analysis (1995), p223, Butterworth-Heinemann.

(2) Seko, S. Ando, Q. Shi, et al, Data Acquisition and Validation Tests for Acoustic Loading Vibration Analysis, 21st Aerospace Testing Seminar, Manhattan Bch., USA, (2003-10), pp.2-71.

(3) G. Badilla et al., VibroAcoustic Payload Environment Prediction System (VAPEPS) Workshop Notes (1991-5), pp.15-13.

(4) McNelis, Mark E., A modified VAPEPS Method for Predicting Vibroacoustic Response of Unreinforced Mass Loaded Honeycomb Panels, NASA-TM-101467 (1989), p3.

(5) Ando, S. et al., the Prediction of Random Acoustic Vibration of Equipment Mounted on Honeycomb Panel, 5th ESA Aerospace Environmental Testing Symposium, Session 5.2, Belgium (2005-6).

(6) Elmer L. Hixson, Mechanical Impedance, Shock and Vibration Handbook (C.M. Harris, Ed.), 5th edition.(2002), p10.12, McGrawHill.

(7) Lyon, R.H. and De Jong, R.G., Theory and Application of Statistical Energy Analysis (1995), p201, Butterworth-Heinemann.

(8) Petersson, B.A.T. et al., Structure-borne Sound, 3rd Edition(2004), p298, Springer.

(9) R. H. Lyon, Statistical Analysis of Power Injection and Response in Structures and Rooms, J. Acoust. Soc. Am., 45, 545565(1969).

(10) Lyon, R.H. and De Jong, R.G., Theory and Application of Statistical Energy Analysis (1995), p140, Butterworth-Heinemann.

(11) Scharton, Terry, VAPEPS at Low Frequencies, JPL Doc. 410-24-3, VAPEPS Newsletter, Issue 3 (1989). 